\title{
Applications of Trauma Informed Approaches in Vocational Education and Training
}

Richard Skiba

LRES Training Management, Melbourne, Australia

\section{ABSTRACT}

This paper utilises a qualitative literature review to highlight the shift to learner-centred methodologies in vocational education and training and profile the applications of trauma informed approaches to address learner needs and increase learner inclusion and chances of success. The discussion begins by identifying the need for trauma informed approaches in delivery related to technical and further education and workplace settings. The characteristics of trauma informed training environments are then considered such that the professional development needs of trainers can be established. The paper presents a model competency statement that can be used to develop training programs for trainers working in vocational education and training. The model competency statement, entitled "Utilise trauma informed training practices", can be used as a basis for development of accredited programs, nationally recognised units of competence, professional development programs or any other program related to implementation of trauma informed approaches in an adult training setting.

Keywords:

Trauma Informed, Adult Learning, Vocational Education, Competency Standards

\section{Discussion}

The Need for Trauma Informed Approaches

Trauma informed approaches can be described as a framework for human service delivery that is based on knowledge and understanding of how trauma affects people's lives and their service needs (Harris \& Fallot, 2001). Harris \& Fallot refer to Burgermeister (2007) to identify that trauma is often a result of adverse childhood experiences, which are defined as perceived negative events that are outside the control of the child, which may hinder normal development, cause harm or the potential for harm, and are accompanied by stress and suffering. Adverse childhood experiences contribute to increased vulnerability to mental health conditions in childhood, adolescence and adult life (Raphael, Stevens, \& Pedersen, 2006 and Dong, Dube, Felitti, Giles, \& Anda, 2003, cited in Harris \& Fallot, 2001). Harris \& Fallot also report that an accumulation of multiple adverse experiences can increase the risk of mental health problems that can impair social and emotional functioning. These mental health problems may affect an individual's ability to undertake formal learning and their chances of success they should do so. If training providers are to address the severe life disruptions and trauma that may in learner populations, they need to be authentically trauma responsive and advocates of social and emotional learning (Desautels, 2020).

Carello and Butler (2015) suggest that there has been a paradigm shift in education toward learner-centred approaches that promote a shift in power from trainer as expert to trainer as facilitator, allowing learners to be experts on their own learning 
and their own lives. The trauma informed approach is consistent with the shift toward a learner-centred approach. Trainers are then responsible for the provision of environments that allow the learner to maximise their learning potential. They also outline that trainers should assume that in virtually every classroom, some unknown subset of learners will be at heightened risk for re-traumatization or vicarious traumatization as a result of personal trauma histories, mental illness experiences, and current challenges or difficult life transitions. This working assumption then obliges trainers to become familiar with the implications of trauma for learning, as well as the signs and symptoms of trauma, re-traumatization, and vicarious traumatization (Carello \& Butler, 2015).

A study by Olesen, McDonald, \& Butterworth (2010), cited in Harris \& Fallot (2001), found that one in five Australian children have been exposed to three or more adverse childhood experiences. For those exposed to adverse childhood experiences, the responses can lead to problems with internalising and externalising problems, such as affect regulation, relationship insecurity, poor socialisation, hyperactivity, disruptive behaviour and poor impulse control. The Australian Institute of Family Studies (2019) quantify that up to $40 \%$ of Australian learners have been exposed to, or witness to, traumatic stressors and approximately one-in-six Australian women $(16 \%)$ and just over one-in-ten Australian men (11\%) experienced abuse before the age of 15 .

Schiffmann (2020), referring to Centers for Disease Control (1997), advises that the impact of adverse childhood experiences does not end with the traumatic exposure in childhood but instead follows people right into adulthood where adverse childhood experiences lead to "social, emotional and cognitive impairment, adoption of healthrisk behaviours, disease, disability, social problems and early death". Schiffmann likewise notes that for designers and facilitators of learning, it can be critical to practices to understand the broad impact of trauma on the brain and its wide reach across the diverse array of adult learners served.

Due to the physical changes in the brain, the trauma-impacted adult moves through life in a state of persistent anxiety and hypervigilance (Schiffmann, 2020). Trauma impacted adult learners are always on the lookout for danger and are hypersensitive to changes in the voice, body posture and facial expressions of others, because those are the early warning signs that he's relied on to stay safe in unsafe situations (Perry, 2006, cited in Schiffmann, 2020). Johnson (2018) postulates that the negative impact from traumatic stress can limit language acquisition, particularly in terms of storing and retrieving new information, including vocabulary and grammar.

An international study (Benjet, Bromet, Kessler, McLaughlin, Ruscio, \& Koenen, 2015, discussed in Johnson, 2018) representing individuals from 24 countries found that over $70 \%$ of respondents experienced at least one potentially traumatic event, and $30.5 \%$ had experienced four or more. Potentially traumatic events include childhood neglect; sexual, physical or emotional abuse; natural disasters; interpersonal violence; and generational or historical traumas.

Research by Wartenweiler (2017) highlights that the traumatized learner has a more difficult school experience and in an educational setting, academic performance, classroom behaviour and social relationships are negatively affected by trauma. Trauma-informed practices in adult education are a relatively new way to create safe learning spaces where traumatized learners can re-shape their learner identity. Desautels (2020) points out that trauma informed approaches are a path to improving learners' learning outcomes and competencies on the basis that unless the learners feel safe and known in their training environment, they do not learn. Minahan (2019) notes that when trainers are proactive and responsive to the needs of learners suffering from traumatic stress and make small changes in the classroom that foster a feeling of safety, it makes a huge difference in their ability to learn. 
Trauma Informed Approach System Characteristics

Orygen (2018) states that there is no universally accepted definition of trauma informed care and outlines that the most widely cited definition within the youth healthcare literature is based on the definition of trauma-informed approaches provided by Substance Abuse and Mental Health Services Administration (SAMHSA) in the USA. SAMSHSA states (Substance Abuse and Mental Health Services Administration, 2018, cited in Orygen, 2018): "A program, organization, or system that is trauma-informed: Realizes the widespread impact of trauma and understands potential paths for recovery; Recognizes the signs and symptoms of trauma in clients, families, staff, and others involved with the system; Responds by fully integrating knowledge about trauma into policies, procedures, and practices; Seeks to actively resist re-traumatization". Havenga (2010) concurs by outlining that trauma informed care and practice is an approach recognising and acknowledging trauma and its prevalence, alongside awareness and sensitivity to its dynamics, in all aspects of service delivery. Although much of the research related to trauma informed approaches is in healthcare, Substance Abuse and Mental Health Services Administration (2014) outlines that the approach is as applicable to other industries and sectors as it is to healthcare and wellbeing, including education.

Kezelman (2014) advises that trauma informed systems understand the dynamics of traumatic stress, survivors in the context of their lives and the role of coping strategies, as contrived by Substance Abuse and Mental Health Services Administration (2014). They feature safety from harm and re-traumatisation, emphasise strength building and skill acquisition rather than symptom management, and foster true collaboration and power sharing between workers and those seeking help at all service levels.

The characteristics of trauma informed approaches will now be defined and considered. Jackson, Frederico, Tanti \& Black (2009) provide elaboration on the notions of safety, trustworthiness and transparency, collaboration and mutuality, empowerment, voice and choice and culture, historical and gender issues; all associated with trauma informed approaches. They outline that safety is provided throughout the organisation, the staff, and the people and family/carers they serve, insofar as that all should feel physically and psychologically safe. This means that the physical setting must be safe and interpersonal interactions must promote a sense of safety. The characteristic of safety is followed by that of trustworthiness and transparency.

In order to establish and build trustworthiness and transparency, organisations are required to create clear expectations with people as to what services will be provided and the methods of delivery. Collaboration and mutuality require true partnering between staff and people. Staff are required to recognise that healing can happen through relationships and in meaningful sharing of power and decision-making. Empowerment occurs through recognition of people's strengths thus empowering them in their development.

A trauma informed approach organisation aims to strengthen the experience of choice for all involved, including staff and clients. The approach recognises every person's experience is unique and requires an individualised approach. Promoting resiliency and coping skills can help individuals manage triggers related to their past experiences of trauma and support healing and self-advocacy. A strengths-based approach to service delivery recognizes the abilities and resilience of trauma survivors, fosters empowerment, and supports an organizational culture of emotional learning and social learning.

Jackson, et al. (2009) further outline that "the trauma informed organisation incorporates policies, protocols, and processes that are responsive to the racial, ethnic, and cultural needs of individuals served, that are gender responsive, and that incorporate a focus on historical trauma". They note that within Australian 
settings, it is particularly important to work in a culturally sensitive way with Aboriginal and Torres Strait Islander young people and families/carers. Wall, Higgins, \& Hunter (2016) present that a trauma-informed approach incorporates processes that move past cultural stereotypes and biases, and incorporates policies, protocols and processes that are responsive to the cultural needs of clients.

To be able to help a traumatised learner, a good understanding of the concept of trauma, and the events that triggered these traumas, can help a trainer be of better assistance to the learner (Adubasim \& Ugwu, 2019). SAMHSA's concept of trauma, cited in Wall, et al. (2016), provides a definition that encompasses trauma related to one-off events as well as ongoing adversity:

"Individual trauma results from an event, series of events or set of circumstances that is experienced by an individual as physically or emotionally harmful or life threatening and that has lasting adverse effects on the individual's functioning and mental, physical, social, emotional or spiritual wellbeing". (Substance Abuse and Mental Health Services Administration, 2014: p. 7)

Harris \& Fallot (2001) note that adverse childhood experiences include family difficulties related to financial struggles, family health problems and losses, parenting impairment due to mental health condition or alcohol and other drug misuse, marital discord and family conflicts. Harris (2017) elaborates that we often think of trauma as an "event", such as an assault or a car accident, however, we now have a much greater understanding of the impact of experiences such as neglect, abuse, poverty, family violence, or lack of a healthy connection with a primary attachment figure. Repetitive traumatic events like these create physiological and psychological responses in children that can last a lifetime (van der Kolk, 2005, 2014; cited in Harris, 2017). To contextualise, Harris outlines that statistics around child protection notifications, the rates of childhood sexual assault, families living with violence and the rates of learners beginning school developmentally vulnerable paint a picture of learners in classrooms across Australia living with trauma in their daily lives.

Numerous research findings (such as Davidson, 2020; Hoch, Stewart, Webb \& Wyandt -Hiebert, 2015) agree that even after a stressful or traumatic situation has ended, people can continue to react as if the stress or trauma is continuing such that they can become self-protective, spend a lot of their energy scanning their environment for threats, act as if they are in a constant state of alarm and may experience a constant baseline feeling of low-level fear, which leaves less space for curiosity, exploration, and learning.

Inclusive Practices

Learning activities go beyond development of technical competence. Learning offers strong social returns in productivity, community participation, political awareness and active citizenry. In a rapidly changing society, with technological advances and growing inequalities, adults must have the opportunity to gain and build their skills and knowledge in order to make informed choices and improve their lives (Adult Learning Australia, 2020). Trainers are obliged to maximise the learning opportunities of their learners by providing suitable environments and practices for effective learning to take place. This includes provision of ongoing engagement, tailored support and a sufficiently flexible learning environment, all requiring an in depth understanding of the learner cohorts and the individuals making them up. A trauma informed approach can contribute to development of this understanding such that practices can be implemented to allow a learner to thrive.

Research has found that many trainers do not know how to identify learners in need of accommodations and how to provide appropriate instruction to fit their learners' needs (Dallas, Sprong, \& Upton, 2014, Polson \& White, 2001; Rocco \& Fornes, 2010, cited in McGinty, 2018). Implementation of any inclusive practice program then commences with trainer and organisational professional development. McGinty 
(2018) suggests that trainers, in absence of professional development, may have to take a trial and error approach to match the appropriate accommodation with the leaner until the learner can successfully navigate their way through the leaning process. Professional development programs may be utilised to ensure that trainers work with learners to determine the best combination of accommodations to ensure their equal participation in the educational environment (McGinty, 2018). With regard to a trauma informed approach, there are a number of practices that could be considered related to promotion of inclusivity. One such practice is the use of course content. Carello \& Butler (2015) note that some course content may have the potential to retraumatize or vicariously traumatize learners.

Carello \& Butler (2015) outline some basic strategies that trainers can use to reduce the potential to retraumatize or vicariously traumatize learners. These include previewing material for appropriateness and eliminate content that is likely to shock or disturb and where difficult material needs to be retained, developing warnings so that learners know what to expect in terms of content, severity, and duration. They further suggest conducting regular check-ins with learners during the class to help determine how learners are doing emotionally and whether adjustments are needed. Assessment requirements should likewise be scrutinized as well for their potential to disturb or trigger learners. They further note that implementing policies and practices that can help learners avoid shame and to feel safe while preparing assignments may reduce risk.

As a cornerstone in trauma informed practices, Carello \& Butler (2015) highlight that allowing learners to not participate demonstrates respect for limits and teaches learners to take responsibility for their own well-being. They also detail that trainers sometimes need to be aware that a learner's reluctance to participate in a given discussion of difficult material, may be an instance of self-protection rather than of resistance, or evidence of lack of preparation. These are important considerations to trainer practice in terms of ensuring safe and inclusive learning environments.

Trainers should also be prepared to provide appropriate and timely referrals including having on hand specific information for referrals to the training provider counselling services, student support services, and/or crisis intervention program. Physical training environment characteristics, must also be considered as they may be triggering for some learners.

Carello \& Butler (2015) recommend soliciting learner feedback and suggestions for improving the safety and comfort of the classroom may help identify and address such specific needs and accommodations. This, in turn, facilitates a more inclusive environment.

Implementing a Trauma Informed Approach

A systems approach to trauma informed care means that implementation goes beyond individual practitioner and service organisation change to extend to whole systems that people who have experienced trauma are likely to interact with (Wall, et al., 2016). Each stage of a client's journey through an organisation offers an opportunity to contribute to their healing. However, services often feel ill-equipped to deal directly with trauma. Wartenweiler (2017) illuminates that he ultimate goal of a trauma informed approach is to create a physically and psychologically safe learning community that allows trauma victims to let down their guard and enables them to focus on learning.

Wartenweiler (2017) explains that Carello and Butler (2015) have developed a framework for face-to-face training environments that includes awareness of the following core elements: some learners in the classroom may be traumatized; some content and assignments may have potential to re-traumatize; instructor and learner behaviour are potentially re-traumatising; classroom characteristics may be unhelpful for traumatised learners; and self-care for both trainer and learners is important. 
From the perspective of teaching practices, Minahan (2019) outlines practices for trainers for effective trauma informed teaching strategies. The first of these is for trainers to expect unexpected responses from learners. Minahan advises that trainers must learn to put learners' reactions into context and not to take them personally. Learners with trauma histories can react and behave in seemingly unexpected ways, such as having a sudden outburst during a favourite activity or crying out of the blue one second after laughing. Trainers may be taken by surprise. This uncertainty leaves the trainer in a constant state of hyper-alertness when interacting with the learner. This in turn can result in fatigue, as the trainer is guarded and unable to predict what will happen from one moment to another.

Trainers must also employ thoughtful interactions. Minahan believes that trainers can reduce problematic behaviour by changing the way they give a direction or respond, they can reduce problematic behaviour. Promotion of predictability is another important activity. This entails providing predictability through visual schedules of the class agenda as a trainer's behaviour can feel unpredictable to traumatized learners. Another significant activity lies in recognizing areas of strength in learners which Minahan suggests is a powerful way to combat the poor selfconcept and negative thinking associated with trauma. Minahan states that It is important that learners experience competence to develop a more accurate selfnarrative and to begin to create a positive future picture of themselves.

From an organisational perspective, Kerka (2002) suggests that establishing a safe space for learning may involve practical actions such as a workable institutional safety plan, financial assistance for shelter/transportation, counselling, child care, access to legal services, flexible entrance requirements and time frames, and a safety audit of the physical environment. Davidson (2020) identifies that all staff members must work together with a sense of shared responsibility for the physical, social, emotional, and academic safety of every learner. Davidson further illuminates that trauma informed approaches are holistic and require a paradigm shift at both the staff and organizational level because they reshape a training provider's culture, practices, and policies. Davidson outlines that choosing a trauma informed approach requires an entire campus community to shift its focus to understanding what happened to a learner rather than fixating on that learner's negative behaviours.

Trauma informed training providers respond to the needs of trauma-exposed learners by integrating effective practices, programs, and procedures into all aspects of the organization and culture. Substance Abuse and Mental Health Services Administration (2014) notes that this often begins with professional development training for all personnel. Further, in the absence of trauma-specific training, trainers fail to recognize trauma's symptoms and lack the resources to reverse its course ( Craig, 2016, cited in Howard, 2018). As such, consideration should be given as to the what should be included in the training for a trainer in a vocational education and training setting. Based on the discussed characteristics and purposes of a trauma informed approach, the following, Table 1 , is proposed as a model unit of competency/accredited module that can be adapted by training providers, accrediting bodies or for any other trainer professional development program.

Overstreet \& Chafouleas (2016) note that trauma focused professional development training typically aims to create a shared understanding of the problem of trauma exposure, build consensus for trauma-informed approaches, and engender attitudes, beliefs, and behaviours conducive to the adoption of system-wide trauma-informed approaches. Any designed training program designed to develop competence in application of a trauma informed approach should meet these objectives.

\section{Conclusion}


Individuals with experiences of trauma are found in all sectors of education and training, including vocational education and training which primarily comprises adult learners. Trauma in individuals has been shown to affect their academic performance and those suffering from trauma, may, if in an inappropriate academic setting, be subject to re-traumatization, and vicarious traumatization. Training environments, organisational policies and procedures and trainer behaviours can all lead to negative outcomes for learners where they do not provide adequate accommodations for the specific learner needs. Trauma informed approaches can be utilised to promote inclusion and minimise the risk of re-traumatization, and vicarious traumatization.

In order to effectively implement a trauma informed approach, professional development is required for trainers such that they are able to contribute to the

Table 1. Model unit of competence specification for a unit designed to specify competence requirements for trainers applying a trauma informed approach in a training environment.

development of the trauma informed approach within their training setting, apply the approach in line with the developed plan, and monitor and review the approach, particularly evaluating the implemented practices such that they can be adjusted as required. There are not current standard definitions of what should be included in a trainer demonstrating competence in implementation and application of trauma informed approaches or practices in vocational education and training and national training systems would benefit from development of such competency standards. This would then allow those implementing the practices to uniformly and consistently apply best practices with a learner-centred focus. Development of national competency standard that is integrated into a national system forms the basis of a shared understanding of trauma informed approaches. These standards could be applied at federal, state or local levels depending on the underpinning education system for the relevant country, given that trauma concepts are universal. Trainer training programs that are comprehensive, theoretically grounded, and practically focused and that seek to align all facets of training with the principles of safety, choice, and collaboration may contribute to increase learner participation and success rates.

\section{Conflicts of Interest}

The author declares no conflicts of interest regarding the publication of this paper.

\section{Cite this paper}

Skiba, R. (2020). Applications of Trauma Informed Approaches in Vocational Education and Training. Creative Education, 11, 488-499. https://doi.org/10.4236/ce.2020.114036

\section{References}

Siayah, Syarofis; \& Setiawan, Adib Rifqi. (2020, April 13). A Brief Explanation of Science Education. EdArXiv. DOI: https://doi.org/10.35542/osf.io/2evn3

Siayah, Syarofis; \& Setiawan, Adib Rifqi. (2020, April 13). A Brief Explanation of Science Education. Thesis Commons. DOI: https://doi.org/10.31237/osf.io/wkvsn 
Setiawan, Adib Rifqi; \& Ilmiyah, Surotul. (2020, April 13). Multiple Intelligences Based on Neuroscience. Thesis Commons. DOI: https://doi.org/10.31237/osf.io/e9fyu

Setiawan, Adib Rifqi; \& Ilmiyah, Surotul. (2020, April 13). Kecerdasan Majemuk Berdasarkan Neurosains. EdArXiv. DOI: https://doi.org/10.35542/osf.io/rj2fe

Setiawan, Adib Rifqi. (2020, April 9). Islamic Education in Southeast Asia. EdArXiv. DOI: https://doi.org/10.35542/osf.io/dnjqv

Ilmiyah, Surotul; \& Setiawan, Adib Rifqi. (2020, April 7). Students' Worksheet for Distance Learning Based on Scientific Literacy in the Topic Coronavirus Disease 2019 (COVID-19). Thesis Commons. DOI: https://doi.org/10.31237/osf.io/fpg4j

Ilmiyah, Surotul; \& Setiawan, Adib Rifqi. (2020, April 7). Students' Worksheet for Distance Learning Based on Scientific Literacy in the Topic Coronavirus Disease 2019 (COVID-19). EdArXiv. DOI: https://doi.org/10.35542/osf.io/wyz5v

Setiawan, Adib Rifqi; \& Ilmiyah, Surotul. (2020, April 7). Lembar Kegiatan Siswa untuk Pembelajaran Jarak Jauh Berdasarkan Literasi Saintifik pada Topik Penyakit Coronavirus 2019 (COVID-19). EdArXiv. DOI: https://doi.org/10.35542/osf.io/h4632

Setiawan, Adib Rifqi. (2020, April 2). Desain Pembelajaran untuk Membimbing Siswa Sekolah Dasar dalam Memperoleh Literasi Saintifik. EdArXiv. DOI: https://doi.org/10.35542/osf.io/u59f8

Velasufah, Whasfi; \& Setiawan, Adib Rifqi. (2020, April 13). Nilai Pesantren Sebagai Dasar Pendidikan Karakter. Thesis Commons. DOI: https://doi.org/10.31237/osf.io/hq6kz

Setiawan, Adib Rifqi. (2020, April 9). Islamic Education in Southeast Asia. Thesis Commons. DOI: https://doi.org/10.31237/osf.io/e794d

Setiawan, Adib Rifqi. (2020, April 2). What is the Best Way to Analyze Pre-Post Data?. EdArXiv. DOI: https://doi.org/10.35542/osf.io/h4e6q

Setiawan, Adib Rifqi. (2020, April 4). Grace Natalie Louisa. SocArXiv. DOI: https://doi.org/10.31235/osf.io/zwf6g

Setiawan, Adib Rifqi. (2020, April 3). Sharifah Halimah Alaydrus : a female preachers for our time. SocArXiv. DOI: https://doi.org/10.31235/osf.io/zb8qe

Setiawan, Adib Rifqi. (2020, April 1). Syarifah Halimah Alaydrus. Thesis Commons. DOI: https://doi.org/10.31237/osf.io/xbmcs

Setiawan, Adib Rifqi. (2020, April 13). Commodification of the Sexuality in Kim Kardashian's Instagram Posts. Thesis Commons. URL: https://thesiscommons.org/mf7nw/

Setiawan, Adib Rifqi. (2020, April 5). The Arrogant One. Thesis Commons. DOI: https://doi.org/10.31237/osf.io/8nmku

Setiawan, Adib Rifqi. (2020, April 4). Grace Natalie Louisa. Thesis Commons. DOI: https://doi.org/10.31237/osf.io/u3mxv

Setiawan, Adib Rifqi. (2020, April 2). JUPE My Uncut Story. Open Science Framework (OSF). DOI: https://doi.org/10.31219/osf.io/qdxga

Setiawan, Adib Rifqi. (2020, April 1). Sharifah Halimah Alaydrus. Thesis Commons. DOI: https://doi.org/10.31237/osf.io/fp79c

Setiawan, Adib Rifqi. (2020, April 13). مبادئ اللغة العربية. Thesis Commons. DOI: https://doi.org/10.31237/osf.io/2gvjf

Siayah, Syarofis; \& Setiawan, Adib Rifqi. (2020, April 13). A Brief Explanation of Science Education. EdArXiv. DOI: https://doi.org/10.35542/osf.io/2evn3

Siayah, Syarofis; \& Setiawan, Adib Rifqi. (2020, April 13). A Brief Explanation of Science Education. Thesis Commons. DOI: https://doi.org/10.31237/osf.io/wkvsn

Setiawan, Adib Rifqi; \& Ilmiyah, Surotul. (2020, April 13). Multiple Intelligences Based on Neuroscience. Thesis Commons. DOI: https://doi.org/10.31237/osf.io/e9fyu

Setiawan, Adib Rifqi; \& Ilmiyah, Surotul. (2020, April 13). Kecerdasan Majemuk Berdasarkan Neurosains. EdArXiv. DOI: https://doi.org/10.35542/osf.io/rj2fe 
Setiawan, Adib Rifqi. (2020, April 9). Islamic Education in Southeast Asia. EdArXiv. DOI: https://doi.org/10.35542/osf.io/dnjqv

Ilmiyah, Surotul; \& Setiawan, Adib Rifqi. (2020, April 7). Students' Worksheet for Distance Learning Based on Scientific Literacy in the Topic Coronavirus Disease 2019 (COVID-19). Thesis Commons. DOI: https://doi.org/10.31237/osf.io/fpg4j

Ilmiyah, Surotul; \& Setiawan, Adib Rifqi. (2020, April 7). Students' Worksheet for Distance Learning Based on Scientific Literacy in the Topic Coronavirus Disease 2019 (COVID-19). EdArXiv. DOI: https://doi.org/10.35542/osf.io/wyz5v

Setiawan, Adib Rifqi; \& Ilmiyah, Surotul. (2020, April 7). Lembar Kegiatan Siswa untuk Pembelajaran Jarak Jauh Berdasarkan Literasi Saintifik pada Topik Penyakit Coronavirus 2019 (COVID-19). EdArXiv. DOI: https://doi.org/10.35542/osf.io/h4632

Setiawan, Adib Rifqi. (2020, April 2). Desain Pembelajaran untuk Membimbing Siswa Sekolah Dasar dalam Memperoleh Literasi Saintifik. EdArXiv. DOI: https://doi.org/10.35542/osf.io/u59f8

Velasufah, Whasfi; \& Setiawan, Adib Rifqi. (2020, April 13). Nilai Pesantren Sebagai Dasar Pendidikan Karakter. Thesis Commons. DOI: https://doi.org/10.31237/osf.io/hq6kz

Setiawan, Adib Rifqi. (2020, April 9). Islamic Education in Southeast Asia. Thesis Commons. DOI: https://doi.org/10.31237/osf.io/e794d

Setiawan, Adib Rifqi. (2020, April 2). What is the Best Way to Analyze Pre-Post Data?. EdArXiv. DOI: https://doi.org/10.35542/osf.io/h4e6q

Setiawan, Adib Rifqi. (2020, April 4). Grace Natalie Louisa. SocArXiv. DOI: https://doi.org/10.31235/osf.io/zwf6g

Setiawan, Adib Rifqi. (2020, April 3). Sharifah Halimah Alaydrus : a female preachers for our time. SocArXiv. DOI: https://doi.org/10.31235/osf.io/zb8qe

Setiawan, Adib Rifqi. (2020, April 1). Syarifah Halimah Alaydrus. Thesis Commons. DOI: https://doi.org/10.31237/osf.io/xbmcs

Setiawan, Adib Rifqi. (2020, April 13). Commodification of the Sexuality in Kim Kardashian's Instagram Posts. Thesis Commons. URL: https://thesiscommons.org/mf7nw/

Setiawan, Adib Rifqi. (2020, April 5). The Arrogant One. Thesis Commons. DOI: https://doi.org/10.31237/osf.io/8nmku

Setiawan, Adib Rifqi. (2020, April 4). Grace Natalie Louisa. Thesis Commons. DOI: https://doi.org/10.31237/osf.io/u3mxv

Setiawan, Adib Rifqi. (2020, April 2). JUPE My Uncut Story. Open Science Framework (OSF). DOI: https://doi.org/10.31219/osf.io/qdxga

Setiawan, Adib Rifqi. (2020, April 1). Sharifah Halimah Alaydrus. Thesis Commons. DOI: https://doi.org/10.31237/osf.io/fp79c

Setiawan, Adib Rifqi. (2020, April 13). مبادئ اللغة العربية. Thesis Commons. DOI: https://doi.org/10.31237/osf.io/2gvjf

Siayah, Syarofis; \& Setiawan, Adib Rifqi. (2020, April 13). A Brief Explanation of Science Education. EdArXiv. DOI: https://doi.org/10.35542/osf.io/2evn3

Siayah, Syarofis; \& Setiawan, Adib Rifqi. (2020, April 13). A Brief Explanation of Science Education. Thesis Commons. DOI: https://doi.org/10.31237/osf.io/wkvsn

Setiawan, Adib Rifai; \& Ilmiyah, Surotul. (2020, April 13). Multiple Intelligences Based on Neuroscience. Thesis Commons. DOI: https://doi.org/10.31237/osf.io/e9fyu

Setiawan, Adib Rifqi; \& Ilmiyah, Surotul. (2020, April 13). Kecerdasan Majemuk Berdasarkan Neurosains. EdArXiv. DOI: https://doi.org/10.35542/osf.io/rj2fe

Setiawan, Adib Rifqi. (2020, April 9). Islamic Education in Southeast Asia. EdArXiv. DOI: https://doi.org/10.35542/osf.io/dnjqv 
Ilmiyah, Surotul; \& Setiawan, Adib Rifqi. (2020, April 7). Students' Worksheet for Distance Learning Based on Scientific Literacy in the Topic Coronavirus Disease 2019 (COVID-19). Thesis Commons. DOI: https://doi.org/10.31237/osf.io/fpg4j

Ilmiyah, Surotul; \& Setiawan, Adib Rifqi. (2020, April 7). Students' Worksheet for Distance Learning Based on Scientific Literacy in the Topic Coronavirus Disease 2019 (COVID-19). EdArXiv. DOI: https://doi.org/10.35542/osf.io/wyz5v

Setiawan, Adib Rifqi; \& Ilmiyah, Surotul. (2020, April 7). Lembar Kegiatan Siswa untuk Pembelajaran Jarak Jauh Berdasarkan Literasi Saintifik pada Topik Penyakit Coronavirus 2019 (COVID-19). EdArXiv. DOI: https://doi.org/10.35542/osf.io/h4632

Setiawan, Adib Rifqi. (2020, April 2). Desain Pembelajaran untuk Membimbing Siswa Sekolah Dasar dalam Memperoleh Literasi Saintifik. EdArXiv. DOI: https://doi.org/10.35542/osf.io/u59f8

Velasufah, Whasfi; \& Setiawan, Adib Rifqi. (2020, April 13). Nilai Pesantren Sebagai Dasar Pendidikan Karakter. Thesis Commons. DOI: https://doi.org/10.31237/osf.io/hq6kz

Setiawan, Adib Rifqi. (2020, April 9). Islamic Education in Southeast Asia. Thesis Commons. DOI: https://doi.org/10.31237/osf.io/e794d

Setiawan, Adib Rifqi. (2020, April 2). What is the Best Way to Analyze Pre-Post Data?. EdArXiv. DOI: https://doi.org/10.35542/osf.io/h4e6q

Setiawan, Adib Rifqi. (2020, April 4). Grace Natalie Louisa. SocArXiv. DOI: https://doi.org/10.31235/osf.io/zwf6g

Setiawan, Adib Rifqi. (2020, April 3). Sharifah Halimah Alaydrus : a female preachers for our time. SocArXiv. DOI: https://doi.org/10.31235/osf.io/zb8qe

Setiawan, Adib Rifqi. (2020, April 1). Syarifah Halimah Alaydrus. Thesis Commons. DOI: https://doi.org/10.31237/osf.io/xbmcs

Setiawan, Adib Rifqi. (2020, April 13). Commodification of the Sexuality in Kim Kardashian's Instagram Posts. Thesis Commons. URL: https://thesiscommons.org/mf7nw/

Setiawan, Adib Rifqi. (2020, April 5). The Arrogant One. Thesis Commons. DOI: https://doi.org/10.31237/osf.io/8nmku

Setiawan, Adib Rifqi. (2020, April 4). Grace Natalie Louisa. Thesis Commons. DOI: https://doi.org/10.31237/osf.io/u3mxv

Setiawan, Adib Rifqi. (2020, April 2). JUPE My Uncut Story. Open Science Framework (OSF). DOI: https://doi.org/10.31219/osf.io/qdxga

Setiawan, Adib Rifqi. (2020, April 1). Sharifah Halimah Alaydrus. Thesis Commons. DOI: https://doi.org/10.31237/osf.io/fp79c

Setiawan, Adib Rifqi. (2020, April 13). مبادئ اللغة العربية. Thesis Commons. DOI: https://doi.org/10.31237/osf.io/2gvjf

Siayah, Syarofis; \& Setiawan, Adib Rifqi. (2020, April 13). A Brief Explanation of Science Education. EdArXiv. DOI: https://doi.org/10.35542/osf.io/2evn3

Siayah, Syarofis; \& Setiawan, Adib Rifqi. (2020, April 13). A Brief Explanation of Science Education. Thesis Commons. DOI: https://doi.org/10.31237/osf.io/wkvsn

Setiawan, Adib Rifqi; \& Ilmiyah, Surotul. (2020, April 13). Multiple Intelligences Based on Neuroscience. Thesis Commons. DOI: https://doi.org/10.31237/osf.io/e9fyu

Setiawan, Adib Rifqi; \& Ilmiyah, Surotul. (2020, April 13). Kecerdasan Majemuk Berdasarkan Neurosains. EdArXiv. DOI: https://doi.org/10.35542/osf.io/rj2fe

Setiawan, Adib Rifqi. (2020, April 9). Islamic Education in Southeast Asia. EdArXiv. DOI: https://doi.org/10.35542/osf.io/dnjqv

Ilmiyah, Surotul; \& Setiawan, Adib Rifqi. (2020, April 7). Students' Worksheet for Distance Learning Based on Scientific Literacy in the Topic Coronavirus Disease 2019 (COVID-19). Thesis Commons. DOI: https://doi.org/10.31237/osf.io/fpg4j 
Ilmiyah, Surotul; \& Setiawan, Adib Rifqi. (2020, April 7). Students' Worksheet for Distance Learning Based on Scientific Literacy in the Topic Coronavirus Disease 2019 (COVID-19). EdArXiv. DOI: https://doi.org/10.35542/osf.io/wyz5v

Setiawan, Adib Rifqi; \& Ilmiyah, Surotul. (2020, April 7). Lembar Kegiatan Siswa untuk Pembelajaran Jarak Jauh Berdasarkan Literasi Saintifik pada Topik Penyakit Coronavirus 2019 (COVID-19). EdArXiv. DOI: https://doi.org/10.35542/osf.io/h4632

Setiawan, Adib Rifqi. (2020, April 2). Desain Pembelajaran untuk Membimbing Siswa Sekolah Dasar dalam Memperoleh Literasi Saintifik. EdArXiv. DOI: https://doi.org/10.35542/osf.io/u59f8

Velasufah, Whasfi; \& Setiawan, Adib Rifqi. (2020, April 13). Nilai Pesantren Sebagai Dasar Pendidikan Karakter. Thesis Commons. DOI: https://doi.org/10.31237/osf.io/hq6kz

Setiawan, Adib Rifqi. (2020, April 9). Islamic Education in Southeast Asia. Thesis Commons. DOI: https://doi.org/10.31237/osf.io/e794d

Setiawan, Adib Rifqi. (2020, April 2). What is the Best Way to Analyze Pre-Post Data?. EdArXiv. DOI: https://doi.org/10.35542/osf.io/h4e6q

Setiawan, Adib Rifqi. (2020, April 4). Grace Natalie Louisa. SocArXiv. DOI: https://doi.org/10.31235/osf.io/zwf6g

Setiawan, Adib Rifqi. (2020, April 3). Sharifah Halimah Alaydrus : a female preachers for our time. SocArXiv. DOI: https://doi.org/10.31235/osf.io/zb8qe

Setiawan, Adib Rifqi. (2020, April 1). Syarifah Halimah Alaydrus. Thesis Commons. DOI: https://doi.org/10.31237/osf.io/xbmcs

Setiawan, Adib Rifqi. (2020, April 13). Commodification of the Sexuality in Kim Kardashian's Instagram Posts. Thesis Commons. URL: https://thesiscommons.org/mf7nw/

Setiawan, Adib Rifqi. (2020, April 5). The Arrogant One. Thesis Commons. DOI: https://doi.org/10.31237/osf.io/8nmku

Setiawan, Adib Rifqi. (2020, April 4). Grace Natalie Louisa. Thesis Commons. DOI: https://doi.org/10.31237/osf.io/u3mxv

Setiawan, Adib Rifqi. (2020, April 2). JUPE My Uncut Story. Open Science Framework (OSF). DOI: https://doi.org/10.31219/osf.io/qdxga

Setiawan, Adib Rifqi. (2020, April 1). Sharifah Halimah Alaydrus. Thesis Commons. DOI: https://doi.org/10.31237/osf.io/fp79c

Setiawan, Adib Rifqi. (2020, April 13). مبادئ اللغة العربية. Thesis Commons. DOI: https://doi.org/10.31237/osf.io/2gvjf

Siayah, Syarofis; \& Setiawan, Adib Rifqi. (2020, April 13). A Brief Explanation of Science Education. EdArXiv. DOI: https://doi.org/10.35542/osf.io/2evn3

Siayah, Syarofis; \& Setiawan, Adib Rifqi. (2020, April 13). A Brief Explanation of Science Education. Thesis Commons. DOI: https://doi.org/10.31237/osf.io/wkvsn

Setiawan, Adib Rifqi; \& Ilmiyah, Surotul. (2020, April 13). Multiple Intelligences Based on Neuroscience. Thesis Commons. DOI: https://doi.org/10.31237/osf.io/e9fyu

Setiawan, Adib Rifqi; \& Ilmiyah, Surotul. (2020, April 13). Kecerdasan Majemuk Berdasarkan Neurosains. EdArXiv. DOI: https://doi.org/10.35542/osf.io/rj2fe

Setiawan, Adib Rifqi. (2020, April 9). Islamic Education in Southeast Asia. EdArXiv. DOI: https://doi.org/10.35542/osf.io/dnjqv

Ilmiyah, Surotul; \& Setiawan, Adib Rifqi. (2020, April 7). Students' Worksheet for Distance Learning Based on Scientific Literacy in the Topic Coronavirus Disease 2019 (COVID-19). Thesis Commons. DOI: https://doi.org/10.31237/osf.io/fpg4j

Ilmiyah, Surotul; \& Setiawan, Adib Rifqi. (2020, April 7). Students' Worksheet for Distance Learning Based on Scientific Literacy in the Topic Coronavirus Disease 2019 (COVID-19). EdArXiv. DOI: https://doi.org/10.35542/osf.io/wyz5v 
Setiawan, Adib Rifqi; \& Ilmiyah, Surotul. (2020, April 7). Lembar Kegiatan Siswa untuk Pembelajaran Jarak Jauh Berdasarkan Literasi Saintifik pada Topik Penyakit Coronavirus 2019 (COVID-19). EdArXiv. DOI:

https://doi.org/10.35542/osf.io/h4632

Setiawan, Adib Rifqi. (2020, April 2). Desain Pembelajaran untuk Membimbing Siswa Sekolah Dasar dalam Memperoleh Literasi Saintifik. EdArXiv. DOI: https://doi.org/10.35542/osf.io/u59f8

Velasufah, Whasfi; \& Setiawan, Adib Rifqi. (2020, April 13). Nilai Pesantren Sebagai Dasar Pendidikan Karakter. Thesis Commons. DOI: https://doi.org/10.31237/osf.io/hq6kz

Setiawan, Adib Rifqi. (2020, April 9). Islamic Education in Southeast Asia. Thesis Commons. DOI: https://doi.org/10.31237/osf.io/e794d

Setiawan, Adib Rifqi. (2020, April 2). What is the Best Way to Analyze Pre-Post Data?. EdArXiv. DOI: https://doi.org/10.35542/osf.io/h4e6q

Setiawan, Adib Rifqi. (2020, April 4). Grace Natalie Louisa. SocArXiv. DOI: https://doi.org/10.31235/osf.io/zwf6g

Setiawan, Adib Rifqi. (2020, April 3). Sharifah Halimah Alaydrus : a female preachers for our time. SocArXiv. DOI: https://doi.org/10.31235/osf.io/zb8qe

Setiawan, Adib Rifqi. (2020, April 1). Syarifah Halimah Alaydrus. Thesis Commons. DOI: https://doi.org/10.31237/osf.io/xbmcs

Setiawan, Adib Rifqi. (2020, April 13). Commodification of the Sexuality in Kim Kardashian's Instagram Posts. Thesis Commons. URL: https://thesiscommons.org/mf7nw/

Setiawan, Adib Rifqi. (2020, April 5). The Arrogant One. Thesis Commons. DOI: https://doi.org/10.31237/osf.io/8nmku

Setiawan, Adib Rifqi. (2020, April 4). Grace Natalie Louisa. Thesis Commons. DOI: https://doi.org/10.31237/osf.io/u3mxv

Setiawan, Adib Rifqi. (2020, April 2). JUPE My Uncut Story. Open Science Framework (OSF). DOI: https://doi.org/10.31219/osf.io/qdxga

Setiawan, Adib Rifqi. (2020, April 1). Sharifah Halimah Alaydrus. Thesis Commons. DOI: https://doi.org/10.31237/osf.io/fp79c

Setiawan, Adib Rifqi. (2020, April 13). مبادئ اللغة العربية. Thesis Commons. DOI: https://doi.org/10.31237/osf.io/2gvjf

Siayah, Syarofis; \& Setiawan, Adib Rifqi. (2020, April 13). A Brief Explanation of Science Education. EdArXiv. DOI: https://doi.org/10.35542/osf.io/2evn3

Siayah, Syarofis; \& Setiawan, Adib Rifqi. (2020, April 13). A Brief Explanation of Science Education. Thesis Commons. DOI: https://doi.org/10.31237/osf.io/wkvsn

Setiawan, Adib Rifqi; \& Ilmiyah, Surotul. (2020, April 13). Multiple Intelligences Based on Neuroscience. Thesis Commons. DOI: https://doi.org/10.31237/osf.io/e9fyu

Setiawan, Adib Rifqi; \& Ilmiyah, Surotul. (2020, April 13). Kecerdasan Majemuk Berdasarkan Neurosains. EdArXiv. DOI: https://doi.org/10.35542/osf.io/rj2fe

Setiawan, Adib Rifqi. (2020, April 9). Islamic Education in Southeast Asia. EdArXiv. DOI: https://doi.org/10.35542/osf.io/dnjqv

Ilmiyah, Surotul; \& Setiawan, Adib Rifqi. (2020, April 7). Students' Worksheet for Distance Learning Based on Scientific Literacy in the Topic Coronavirus Disease 2019 (COVID-19). Thesis Commons. DOI: https://doi.org/10.31237/osf.io/fpg4j

Ilmiyah, Surotul; \& Setiawan, Adib Rifqi. (2020, April 7). Students' Worksheet for Distance Learning Based on Scientific Literacy in the Topic Coronavirus Disease 2019 (COVID-19). EdArXiv. DOI: https://doi.org/10.35542/osf.io/wyz5v

Setiawan, Adib Rifqi; \& Ilmiyah, Surotul. (2020, April 7). Lembar Kegiatan Siswa untuk Pembelajaran Jarak Jauh Berdasarkan Literasi Saintifik pada Topik Penyakit Coronavirus 2019 (COVID-19). EdArXiv. DOI:

https://doi.org/10.35542/osf.io/h4632 
Setiawan, Adib Rifqi. (2020, April 2). Desain Pembelajaran untuk Membimbing Siswa Sekolah Dasar dalam Memperoleh Literasi Saintifik. EdArXiv. DOI: https://doi.org/10.35542/osf.io/u59f8

Velasufah, Whasfi; \& Setiawan, Adib Rifqi. (2020, April 13). Nilai Pesantren Sebagai Dasar Pendidikan Karakter. Thesis Commons. DOI:

https://doi.org/10.31237/osf.io/hq6kz

Setiawan, Adib Rifqi. (2020, April 9). Islamic Education in Southeast Asia. Thesis Commons. DOI: https://doi.org/10.31237/osf.io/e794d

Setiawan, Adib Rifqi. (2020, April 2). What is the Best Way to Analyze Pre-Post Data?. EdArXiv. DOI: https://doi.org/10.35542/osf.io/h4e6q

Setiawan, Adib Rifqi. (2020, April 4). Grace Natalie Louisa. SocArXiv. DOI: https://doi.org/10.31235/osf.io/zwf6g

Setiawan, Adib Rifqi. (2020, April 3). Sharifah Halimah Alaydrus : a female preachers for our time. SocArXiv. DOI: https://doi.org/10.31235/osf.io/zb8qe

Setiawan, Adib Rifqi. (2020, April 1). Syarifah Halimah Alaydrus. Thesis Commons. DOI: https://doi.org/10.31237/osf.io/xbmcs

Setiawan, Adib Rifqi. (2020, April 13). Commodification of the Sexuality in Kim Kardashian's Instagram Posts. Thesis Commons. URL: https://thesiscommons.org/mf7nw/

Setiawan, Adib Rifqi. (2020, April 5). The Arrogant One. Thesis Commons. DOI: https://doi.org/10.31237/osf.io/8nmku

Setiawan, Adib Rifqi. (2020, April 4). Grace Natalie Louisa. Thesis Commons. DOI: https://doi.org/10.31237/osf.io/u3mxv

Setiawan, Adib Rifqi. (2020, April 2). JUPE My Uncut Story. Open Science Framework (OSF). DOI: https://doi.org/10.31219/osf.io/qdxga

Setiawan, Adib Rifqi. (2020, April 1). Sharifah Halimah Alaydrus. Thesis Commons. DOI: https://doi.org/10.31237/osf.io/fp79c

Setiawan, Adib Rifqi. (2020, April 13). مبادئ اللغة العربية. Thesis Commons. DOI: https://doi.org/10.31237/osf.io/2gvjf

Siayah, Syarofis; \& Setiawan, Adib Rifqi. (2020, April 13). A Brief Explanation of Science Education. EdArXiv. DOI: https://doi.org/10.35542/osf.io/2evn3

Siayah, Syarofis; \& Setiawan, Adib Rifqi. (2020, April 13). A Brief Explanation of Science Education. Thesis Commons. DOI: https://doi.org/10.31237/osf.io/wkvsn

Setiawan, Adib Rifqi; \& Ilmiyah, Surotul. (2020, April 13). Multiple Intelligences Based on Neuroscience. Thesis Commons. DOI: https://doi.org/10.31237/osf.io/e9fyu

Setiawan, Adib Rifqi; \& Ilmiyah, Surotul. (2020, April 13). Kecerdasan Majemuk Berdasarkan Neurosains. EdArXiv. DOI: https://doi.org/10.35542/osf.io/rj2fe

Setiawan, Adib Rifqi. (2020, April 9). Islamic Education in Southeast Asia. EdArXiv. DOI: https://doi.org/10.35542/osf.io/dnjqv

Ilmiyah, Surotul; \& Setiawan, Adib Rifqi. (2020, April 7). Students' Worksheet for Distance Learning Based on Scientific Literacy in the Topic Coronavirus Disease 2019 (COVID-19). Thesis Commons. DOI: https://doi.org/10.31237/osf.io/fpg4j

Ilmiyah, Surotul; \& Setiawan, Adib Rifqi. (2020, April 7). Students' Worksheet for Distance Learning Based on Scientific Literacy in the Topic Coronavirus Disease 2019 (COVID-19). EdArXiv. DOI: https://doi.org/10.35542/osf.io/wyz5v

Setiawan, Adib Rifqi; \& Ilmiyah, Surotul. (2020, April 7). Lembar Kegiatan Siswa untuk Pembelajaran Jarak Jauh Berdasarkan Literasi Saintifik pada Topik Penyakit Coronavirus 2019 (COVID-19). EdArXiv. DOI: https://doi.org/10.35542/osf.io/h4632

Setiawan, Adib Rifqi. (2020, April 2). Desain Pembelajaran untuk Membimbing Siswa Sekolah Dasar dalam Memperoleh Literasi Saintifik. EdArXiv. DOI: https://doi.org/10.35542/osf.io/u59f8 
Velasufah, Whasfi; \& Setiawan, Adib Rifqi. (2020, April 13). Nilai Pesantren Sebagai Dasar Pendidikan Karakter. Thesis Commons. DOI:

https://doi.org/10.31237/osf.io/hq6kz

Setiawan, Adib Rifqi. (2020, April 9). Islamic Education in Southeast Asia. Thesis Commons. DOI: https://doi.org/10.31237/osf.io/e794d

Setiawan, Adib Rifqi. (2020, April 2). What is the Best Way to Analyze Pre-Post Data?. EdArXiv. DOI: https://doi.org/10.35542/osf.io/h4e6q

Setiawan, Adib Rifqi. (2020, April 4). Grace Natalie Louisa. SocArXiv. DOI: https://doi.org/10.31235/osf.io/zwf6g

Setiawan, Adib Rifqi. (2020, April 3). Sharifah Halimah Alaydrus : a female preachers for our time. SocArXiv. DOI: https://doi.org/10.31235/osf.io/zb8qe

Setiawan, Adib Rifqi. (2020, April 1). Syarifah Halimah Alaydrus. Thesis Commons. DOI: https://doi.org/10.31237/osf.io/xbmcs

Setiawan, Adib Rifqi. (2020, April 13). Commodification of the Sexuality in Kim Kardashian's Instagram Posts. Thesis Commons. URL: https://thesiscommons.org/mf7nw/

Setiawan, Adib Rifqi. (2020, April 5). The Arrogant One. Thesis Commons. DOI: https://doi.org/10.31237/osf.io/8nmku

Setiawan, Adib Rifqi. (2020, April 4). Grace Natalie Louisa. Thesis Commons. DOI: https://doi.org/10.31237/osf.io/u3mxv

Setiawan, Adib Rifqi. (2020, April 2). JUPE My Uncut Story. Open Science Framework (OSF). DOI: https://doi.org/10.31219/osf.io/qdxga

Setiawan, Adib Rifqi. (2020, April 1). Sharifah Halimah Alaydrus. Thesis Commons. DOI: https://doi.org/10.31237/osf.io/fp79c

Setiawan, Adib Rifqi. (2020, April 13). مبادئ اللغة العربية. Thesis Commons. DOI: https://doi.org/10.31237/osf.io/2gvjf

Siayah, Syarofis; \& Setiawan, Adib Rifqi. (2020, April 13). A Brief Explanation of Science Education. EdArXiv. DOI: https://doi.org/10.35542/osf.io/2evn3

Siayah, Syarofis; \& Setiawan, Adib Rifqi. (2020, April 13). A Brief Explanation of Science Education. Thesis Commons. DOI: https://doi.org/10.31237/osf.io/wkvsn

Setiawan, Adib Rifqi; \& Ilmiyah, Surotul. (2020, April 13). Multiple Intelligences Based on Neuroscience. Thesis Commons. DOI: https://doi.org/10.31237/osf.io/e9fyu

Setiawan, Adib Rifqi; \& Ilmiyah, Surotul. (2020, April 13). Kecerdasan Majemuk Berdasarkan Neurosains. EdArXiv. DOI: https://doi.org/10.35542/osf.io/rj2fe

Setiawan, Adib Rifqi. (2020, April 9). Islamic Education in Southeast Asia. EdArXiv. DOI: https://doi.org/10.35542/osf.io/dnjqv

Ilmiyah, Surotul; \& Setiawan, Adib Rifqi. (2020, April 7). Students' Worksheet for Distance Learning Based on Scientific Literacy in the Topic Coronavirus Disease 2019 (COVID-19). Thesis Commons. DOI: https://doi.org/10.31237/osf.io/fpg4j

Ilmiyah, Surotul; \& Setiawan, Adib Rifqi. (2020, April 7). Students' Worksheet for Distance Learning Based on Scientific Literacy in the Topic Coronavirus Disease 2019 (COVID-19). EdArXiv. DOI: https://doi.org/10.35542/osf.io/wyz5v

Setiawan, Adib Rifqi; \& Ilmiyah, Surotul. (2020, April 7). Lembar Kegiatan Siswa untuk Pembelajaran Jarak Jauh Berdasarkan Literasi Saintifik pada Topik Penyakit Coronavirus 2019 (COVID-19). EdArXiv. DOI: https://doi.org/10.35542/osf.io/h4632

Setiawan, Adib Rifqi. (2020, April 2). Desain Pembelajaran untuk Membimbing Siswa Sekolah Dasar dalam Memperoleh Literasi Saintifik. EdArXiv. DOI: https://doi.org/10.35542/osf.io/u59f8

Velasufah, Whasfi; \& Setiawan, Adib Rifqi. (2020, April 13). Nilai Pesantren Sebagai Dasar Pendidikan Karakter. Thesis Commons. DOI:

https://doi.org/10.31237/osf.io/hq6kz 
Setiawan, Adib Rifqi. (2020, April 9). Islamic Education in Southeast Asia. Thesis Commons. DOI: https://doi.org/10.31237/osf.io/e794d

Setiawan, Adib Rifqi. (2020, April 2). What is the Best Way to Analyze Pre-Post Data?. EdArXiv. DOI: https://doi.org/10.35542/osf.io/h4e6q

Setiawan, Adib Rifqi. (2020, April 4). Grace Natalie Louisa. SocArXiv. DOI: https://doi.org/10.31235/osf.io/zwf6g

Setiawan, Adib Rifqi. (2020, April 3). Sharifah Halimah Alaydrus : a female preachers for our time. SocArXiv. DOI: https://doi.org/10.31235/osf.io/zb8qe

Setiawan, Adib Rifqi. (2020, April 1). Syarifah Halimah Alaydrus. Thesis Commons. DOI: https://doi.org/10.31237/osf.io/xbmcs

Setiawan, Adib Rifqi. (2020, April 13). Commodification of the Sexuality in Kim Kardashian's Instagram Posts. Thesis Commons. URL: https://thesiscommons.org/mf7nw/

Setiawan, Adib Rifqi. (2020, April 5). The Arrogant One. Thesis Commons. DOI: https://doi.org/10.31237/osf.io/8nmku

Setiawan, Adib Rifqi. (2020, April 4). Grace Natalie Louisa. Thesis Commons. DOI: https://doi.org/10.31237/osf.io/u3mxv

Setiawan, Adib Rifqi. (2020, April 2). JUPE My Uncut Story. Open Science Framework (OSF). DOI: https://doi.org/10.31219/osf.io/qdxga

Setiawan, Adib Rifqi. (2020, April 1). Sharifah Halimah Alaydrus. Thesis Commons. DOI: https://doi.org/10.31237/osf.io/fp79c

Setiawan, Adib Rifqi. (2020, April 13). مبادئ اللغة العربية. Thesis Commons. DOI: https://doi.org/10.31237/osf.io/2gvjf

Siayah, Syarofis; \& Setiawan, Adib Rifqi. (2020, April 13). A Brief Explanation of Science Education. EdArXiv. DOI: https://doi.org/10.35542/osf.io/2evn3

Siayah, Syarofis; \& Setiawan, Adib Rifqi. (2020, April 13). A Brief Explanation of Science Education. Thesis Commons. DOI: https://doi.org/10.31237/osf.io/wkvsn

Setiawan, Adib Rifqi; \& Ilmiyah, Surotul. (2020, April 13). Multiple Intelligences Based on Neuroscience. Thesis Commons. DOI: https://doi.org/10.31237/osf.io/e9fyu

Setiawan, Adib Rifqi; \& Ilmiyah, Surotul. (2020, April 13). Kecerdasan Majemuk Berdasarkan Neurosains. EdArXiv. DOI: https://doi.org/10.35542/osf.io/rj2fe

Setiawan, Adib Rifqi. (2020, April 9). Islamic Education in Southeast Asia. EdArXiv. DOI: https://doi.org/10.35542/osf.io/dnjqv

Ilmiyah, Surotul; \& Setiawan, Adib Rifqi. (2020, April 7). Students' Worksheet for Distance Learning Based on Scientific Literacy in the Topic Coronavirus Disease 2019 (COVID-19). Thesis Commons. DOI: https://doi.org/10.31237/osf.io/fpg4j

Ilmiyah, Surotul; \& Setiawan, Adib Rifqi. (2020, April 7). Students' Worksheet for Distance Learning Based on Scientific Literacy in the Topic Coronavirus Disease 2019 (COVID-19). EdArXiv. DOI: https://doi.org/10.35542/osf.io/wyz5v

Setiawan, Adib Rifqi; \& Ilmiyah, Surotul. (2020, April 7). Lembar Kegiatan Siswa untuk Pembelajaran Jarak Jauh Berdasarkan Literasi Saintifik pada Topik Penyakit Coronavirus 2019 (COVID-19). EdArXiv. DOI: https://doi.org/10.35542/osf.io/h4632

Setiawan, Adib Rifqi. (2020, April 2). Desain Pembelajaran untuk Membimbing Siswa Sekolah Dasar dalam Memperoleh Literasi Saintifik. EdArXiv. DOI: https://doi.org/10.35542/osf.io/u59f8

Velasufah, Whasfi; \& Setiawan, Adib Rifqi. (2020, April 13). Nilai Pesantren Sebagai Dasar Pendidikan Karakter. Thesis Commons. DOI: https://doi.org/10.31237/osf.io/hq6kz

Setiawan, Adib Rifqi. (2020, April 9). Islamic Education in Southeast Asia. Thesis Commons. DOI: https://doi.org/10.31237/osf.io/e794d

Setiawan, Adib Rifqi. (2020, April 2). What is the Best Way to Analyze Pre-Post Data?. EdArXiv. DOI: https://doi.org/10.35542/osf.io/h4e6q 
Setiawan, Adib Rifqi. (2020, April 4). Grace Natalie Louisa. SocArXiv. DOI: https://doi.org/10.31235/osf.io/zwf6g

Setiawan, Adib Rifqi. (2020, April 3). Sharifah Halimah Alaydrus : a female preachers for our time. SocArXiv. DOI: https://doi.org/10.31235/osf.io/zb8qe

Setiawan, Adib Rifqi. (2020, April 1). Syarifah Halimah Alaydrus. Thesis Commons. DOI: https://doi.org/10.31237/osf.io/xbmcs

Setiawan, Adib Rifqi. (2020, April 13). Commodification of the Sexuality in Kim Kardashian's Instagram Posts. Thesis Commons. URL: https://thesiscommons.org/mf7nw/

Setiawan, Adib Rifqi. (2020, April 5). The Arrogant One. Thesis Commons. DOI: https://doi.org/10.31237/osf.io/8nmku

Setiawan, Adib Rifqi. (2020, April 4). Grace Natalie Louisa. Thesis Commons. DOI: https://doi.org/10.31237/osf.io/u3mxv

Setiawan, Adib Rifqi. (2020, April 2). JUPE My Uncut Story. Open Science Framework (OSF). DOI: https://doi.org/10.31219/osf.io/qdxga

Setiawan, Adib Rifqi. (2020, April 1). Sharifah Halimah Alaydrus. Thesis Commons. DOI: https://doi.org/10.31237/osf.io/fp79c

Setiawan, Adib Rifqi. (2020, April 13). مبادئ اللغة العربية. Thesis Commons. DOI: https://doi.org/10.31237/osf.io/2gvjf

Siayah, Syarofis; \& Setiawan, Adib Rifqi. (2020, April 13). A Brief Explanation of Science Education. EdArXiv. DOI: https://doi.org/10.35542/osf.io/2evn3

Siayah, Syarofis; \& Setiawan, Adib Rifqi. (2020, April 13). A Brief Explanation of Science Education. Thesis Commons. DOI: https://doi.org/10.31237/osf.io/wkvsn

Setiawan, Adib Rifqi; \& Ilmiyah, Surotul. (2020, April 13). Multiple Intelligences Based on Neuroscience. Thesis Commons. DOI: https://doi.org/10.31237/osf.io/e9fyu

Setiawan, Adib Rifqi; \& Ilmiyah, Surotul. (2020, April 13). Kecerdasan Majemuk Berdasarkan Neurosains. EdArXiv. DOI: https://doi.org/10.35542/osf.io/rj2fe

Setiawan, Adib Rifqi. (2020, April 9). Islamic Education in Southeast Asia. EdArXiv. DOI: https://doi.org/10.35542/osf.io/dnjqv

Ilmiyah, Surotul; \& Setiawan, Adib Rifqi. (2020, April 7). Students' Worksheet for Distance Learning Based on Scientific Literacy in the Topic Coronavirus Disease 2019 (COVID-19). Thesis Commons. DOI: https://doi.org/10.31237/osf.io/fpg4j

Ilmiyah, Surotul; \& Setiawan, Adib Rifqi. (2020, April 7). Students' Worksheet for Distance Learning Based on Scientific Literacy in the Topic Coronavirus Disease 2019 (COVID-19). EdArXiv. DOI: https://doi.org/10.35542/osf.io/wyz5v

Setiawan, Adib Rifqi; \& Ilmiyah, Surotul. (2020, April 7). Lembar Kegiatan Siswa untuk Pembelajaran Jarak Jauh Berdasarkan Literasi Saintifik pada Topik Penyakit Coronavirus 2019 (COVID-19). EdArXiv. DOI: https://doi.org/10.35542/osf.io/h4632

Setiawan, Adib Rifqi. (2020, April 2). Desain Pembelajaran untuk Membimbing Siswa Sekolah Dasar dalam Memperoleh Literasi Saintifik. EdArXiv. DOI: https://doi.org/10.35542/osf.io/u59f8

Velasufah, Whasfi; \& Setiawan, Adib Rifqi. (2020, April 13). Nilai Pesantren Sebagai Dasar Pendidikan Karakter. Thesis Commons. DOI:

https://doi.org/10.31237/osf.io/hq6kz

Setiawan, Adib Rifqi. (2020, April 9). Islamic Education in Southeast Asia. Thesis Commons. DOI: https://doi.org/10.31237/osf.io/e794d

Setiawan, Adib Rifqi. (2020, April 2). What is the Best Way to Analyze Pre-Post Data?. EdArXiv. DOI: https://doi.org/10.35542/osf.io/h4e6q

Setiawan, Adib Rifqi. (2020, April 4). Grace Natalie Louisa. SocArXiv. DOI: https://doi.org/10.31235/osf.io/zwf6g

Setiawan, Adib Rifqi. (2020, April 3). Sharifah Halimah Alaydrus : a female preachers for our time. SocArXiv. DOI: https://doi.org/10.31235/osf.io/zb8qe 


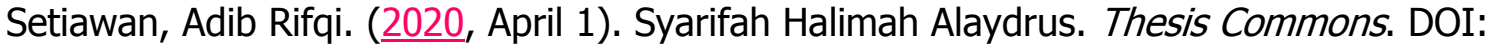
https://doi.org/10.31237/osf.io/xbmcs

Setiawan, Adib Rifqi. (2020, April 13). Commodification of the Sexuality in Kim Kardashian's Instagram Posts. Thesis Commons. URL: https://thesiscommons.org/mf7nw/

Setiawan, Adib Rifqi. (2020, April 5). The Arrogant One. Thesis Commons. DOI: https://doi.org/10.31237/osf.io/8nmku

Setiawan, Adib Rifqi. (2020, April 4). Grace Natalie Louisa. Thesis Commons. DOI: https://doi.org/10.31237/osf.io/u3mxv

Setiawan, Adib Rifqi. (2020, April 2). JUPE My Uncut Story. Open Science Framework (OSF). DOI: https://doi.org/10.31219/osf.io/qdxga

Setiawan, Adib Rifqi. (2020, April 1). Sharifah Halimah Alaydrus. Thesis Commons. DOI: https://doi.org/10.31237/osf.io/fp79c

Setiawan, Adib Rifqi. (2020, April 13). مبادئ اللغة العربية. Thesis Commons. DOI: https://doi.org/10.31237/osf.io/2gvjf 